\title{
Business English as a Lingua Franca (BELF)
}

\author{
Yan $\mathrm{Wu}^{1}$ \\ ${ }^{1}$ College of Foreign Languages, Hebei United University, Tangshan, Hebei, China \\ Correspondence: Yan Wu, College of Foreign Languages, Hebei United University, No. 46 West Xinhua Road, \\ Tangshan, Hebei, China. Tel: 86-139-3155-3695. E-mail: helenawuyan@126.com
}

$\begin{array}{lr}\text { Received: August 7, } 2013 & \text { Accepted: September 22, } 2013 \quad \text { Online Published: September 28, } 2013 \\ \text { doi:10.5539/ies.v6n10p130 } & \text { URL: http://dx.doi.org/10.5539/ies.v6n10p130 }\end{array}$

\begin{abstract}
This paper examines BELF (Business English as a Lingua Franca) teaching and researching in China. A literature review is conducted using the China National Knowledge Infrastructure (CNKI) database. This survey includes a cursory literature search on BELF and a thorough literature study of 12 Chinese major academic journals. From the data collected in this study several findings emerge. First, BELF teaching and research has been on the rise since the founding of the People's Republic of China; and it appears that there will continue to be a growth in BELF literature and research. Secondly, BELF literature during this period has covered a wide range of areas, such as teaching methodology, mode and learning strategies, syllabus design, course assessment and reform, translation studies, systemic functional based studies, discourse studies, as well as other areas. Thirdly, some drawbacks are also exposed. For example, the paucity of empirical studies indicates a strong need to improve the quantity of BELF research literature.
\end{abstract}

Keywords: Business English (BE), Lingua Franca (LF), BELF teaching and research

\section{The Definition of BELF}

BELF (Business English as a Lingua Franca or English Lingua Franca for Business Purposes) is employed as a substitute for BE (Business English) because of the wider application of Business English in international business communications among nonnative speakers. In addition to it, the focus of teaching and researching in BELF is certainly wider than that in BE. BELF covers both the teaching and researching of Business English with the purposes of facilitating both business communications between speakers of other languages and NS (native English speakers), and between NNS (nonnative speakers).

Although the core definition of BELF has much in common with that of BE, the former differs from the latter in some aspects. There is a brief introduction to the definition of BE by domestic and overseas scholars.

Mark Ellis and Christine Johnson in their book "Teaching Business English" (1994, pp. 7-13) have defined the characteristics of BE from five aspects:

1) "Much of the language needed by business people (apart from social language) will be transactional."

2) "Social contacts are often highly ritualized."

3) Clear information should be conveyed within a short time.

4) The language used in business "will be neither as rich in vocabulary and expression nor as culture-bound, as that used by native speakers, but will be based on a core of the most useful and basic structures and vocabulary."

5) Business English courses differ greatly in some aspects like needs analysis, assessment of level, syllabus, course objectives, etc.

Jiang and Guo (1997, pp. 43-50) have explored BE in comparison with General English (GE). The major differences between them lie in the goal of teaching and materials in use.

Lin (2004) defines international business English from four aspects:

a) From the perspective of ESP, it can be defined as an attitude or viewpoint in dealing with language in international business communications, rather than an innovative or creative work. 
b) It is an international language, which draws distinction in accordance with native English or Standard English.

c) As a major well-developed branch of ESP, its teaching falls into EGBP (English for General Business Purposes) and ESBP (English for Specific Business Purposes).

d) It should take learners' needs into account and show respect for individual differences.

As is shown above, there is not a universally acknowledged definition of BE. The multi-disciplinary characteristics of BE may contribute to the diversity of its definitions. While there is some overlap with BE, BELF covers a wide variety of English usage in many industries, such as finance, economics, business law, foreign trade, tourism, advertising, etc. Taking this into account, BELF falls into two categories, namely, ELFGBP (English Lingua Franca for General Business Purposes) and ELFSBP (English Lingua Franca for Specific Business Purposes). The former is defined in accordance with the core features of Business English. While the latter is definedin accordance with the diversities in various levels of language as well as the specific context English language in use.

\section{BELF Teaching and Research in China -A Historial Review}

Business English (BE) has been taught in China ever since the founding of the People's Republic of China. The development of Business English can be observed in teaching goals, courses offered, and materials used. 1n the 1950s, Business English teaching was aimed at producing translators and interpreters in the field of foreign trade. Only a few colleges offered Business English Translation programs. In the 1980s, it was aimed at teaching students both the English language and a way of conducting business. Content-based courses were offered in English, such as marketing, management, and international co-operation. It was believed that by providing students with an English language environment, they could learn both language and business knowledge naturally. During the 1990s, Business English underwent a considerable development. And business English teaching was considered a way to cultivate multi-talents. This transformation led to colleges and universities at different levels to start offering a variety of business English courses. Since the beginning of 21 st century, although Business English remains a way of cultivating multi-talents, the literature research (see Table 1) in this field has shown that many colleges, universities, scholars and teachers have taken initiative to explore BE in terms of teaching methods and modes, teaching materials, etc., and they have endeavored to relate theories to practice which is totally different from intuition-oriented (See Table $3 \& 4$ ).

\section{Literature Research}

\subsection{Research Methods}

Following is a literature research on journal papers already published in China. All the literature is from Chinese major academic journals in the field of foreign languages, including 12 journals: Foreign Language Teaching and Research, Foreign Language World, Foreign Language and Literature, Foreign Languages Research, Foreign Language Learning Theory and Practice, Modern Foreign Languages, Foreign Languages and Their Teaching, Foreign Language Education, Journal of PLA University of Foreign Languages, Foreign Language Research, Shandong Foreign Language Teaching Journal, Journal of Foreign Language. All the data are provided by CNKI (China National Knowledge Infrastructure) .

\subsection{Data Analysis}

By searching the CNKI (China National Knowledge Infrastructure) database for key words: Business English, or its Chinese correspondence, 商务英语, 商贸英语, 经贸英语, 外贸英语, the data collected shows that during the period of Jan. $1^{\text {st }}, 1949$ to Jan. $1^{\text {st }}, 2012$, we can see that there are 8672 articles in this field. Only one of the articles is from before Jan. $1^{\text {st }}, 1978$ and 35 are during the period of Jan. $2^{\text {nd }}, 1978$ to Jan. $1^{\text {st }}, 1990$. However, the amount of articles rose from 623 (between Jan. $2^{\text {nd }}, 1990$ and Jan. $1^{\text {st }}, 2000$ ) to 8013 (between Jan. $2^{\text {nd }}, 2000$ and Jan. $\left.1^{\text {st }}, 2012\right)$. Table 1 shows this sharp increase in the amount of BELF articles during the last decade.

Table 1. Brief Overview on BELF Teaching and Researching in China since the Founding of the PRC

\begin{tabular}{llllll}
\hline \multirow{2}{*}{ Period of time } & \multirow{2}{*}{${\text { Before Jan. } 1^{\text {st }}, 1978}$} & $\begin{array}{l}\text { Jan. } 2^{\text {nd }}, 1978- \\
\text { Jan. } 1^{\text {st }}, 1990\end{array}$ & $\begin{array}{l}\text { Jan. } 2^{\text {nd }}, 1990-- \\
\text { Jan. } 1^{\text {st }}, 2000\end{array}$ & $\begin{array}{l}\text { Jan. } 2^{\text {nd }}, 2000- \\
\text { Jan. } 1^{\text {st }}, 2012\end{array}$ & Total \\
\hline Search results & 1 & 35 & 623 & 8013 & 8672 \\
\hline
\end{tabular}


Though BELF teaching started shortly after the founding of the PRC, Table 1 illustrates a couple of facts. As is known, BE research dates back to the 1980s overseas. Therefore, BELF research had developed slowly for 10 years in the PRC. Secondly, since 1990s, BELF teaching and researching has been developing from intuition-oriented towards rational or theory-guided practice. Scholars started thinking and conducting research on BELF in a more scientific way. Thirdly, BELF literature has increased since Jan. 1st, 1990, and the last decade has witnessed a considerable increase.

Why is there a sharp increase in the amount of literature during the last decade? The possible reasons may be:

1) After implementing the China Open Door Policies in 1978, especially after China's successfully entry into the World Trade Organization (WTO), there's been an increasing demand for proficient English language users with business expertise.

2) In the 1980s, a lot of theories were introduced to China, such as ESP and Systemic Functional Linguistics. These have profound influences on BELF researching and teaching methods.

3) During the 1990s, the Ministry of Education recognized that Business English teaching was a method of cultivating multi-talented individuals. Since this point, colleges and universities at various levels started offering Business English courses.

4) The globalization trend has also contributed to the rapid growth in BELF literature.

In order to develop a thorough understanding of BELF teaching and researching in China, a literature search was conducted of 12 major academic journals in the field of foreign languages. These journals were selected because they are highly-regarded in China. In addition, the papers included in these journals are professional and of higher quality.

The results show that there are 87 papers related to BELF teaching and research published since 1981 . The distribution of which is shown in Table 2. Only eleven journals are included in Table 2 because no literature in BELF was found in the Foreign Language Teaching and Research journal.

Table 2. Distribution of Academic Journals and BELF Articles

\begin{tabular}{|c|c|c|c|c|c|c|c|c|c|c|c|c|c|}
\hline Year $(1981-2012)$ Journals & 1 & 2 & 3 & 4 & 5 & 6 & 7 & 8 & 9 & 10 & 11 & Total & $\begin{array}{l}\text { Percentage } \\
(\%)\end{array}$ \\
\hline 1981 & & & & 1 & 1 & & & & & & & 2 & 2.30 \\
\hline 1993 & & & & & 1 & & 1 & & & & & 2 & 2.30 \\
\hline 1994 & & & & 1 & & & & & & & & 1 & 1.15 \\
\hline 1995 & & & & 1 & & 1 & & & & & 1 & 3 & 3.45 \\
\hline 1996 & & & & & & & & & & & 1 & 1 & 1.15 \\
\hline 1997 & 1 & & & & & & 1 & 1 & 1 & 1 & & 5 & 5.75 \\
\hline 1998 & & & & & & & & & & 2 & 1 & 3 & 3.45 \\
\hline 1999 & & & & & & & & & 2 & 2 & & 4 & 4.60 \\
\hline 2000 & & & & 1 & & & & & & & 1 & 2 & 2.30 \\
\hline 2001 & & & & & & & & & & 1 & 1 & 2 & 2.30 \\
\hline 2002 & & & & & & & 2 & & & & & 2 & 2.30 \\
\hline 2003 & & & & 1 & & & 1 & & & & & 2 & 2.30 \\
\hline 2004 & & & 1 & 1 & & & & & & 3 & & 5 & 5.75 \\
\hline 2005 & 1 & & & & & & 2 & & & 2 & 1 & 6 & 6.90 \\
\hline 2006 & 2 & 1 & & & & & 2 & & & 2 & 1 & 8 & 9.20 \\
\hline 2007 & & 1 & & 1 & & & 2 & & & & 2 & 6 & 6.90 \\
\hline 2008 & 2 & & & & & & 2 & & & & 2 & 6 & 6.90 \\
\hline 2009 & & 2 & & & & 1 & 1 & & & 1 & 1 & 6 & 6.90 \\
\hline 2010 & & 2 & & & 1 & 4 & 1 & & & 1 & & 9 & 10.35 \\
\hline
\end{tabular}




$\begin{array}{llllllllllllll}2011 & & 2 & & & & 3 & 1 & & 1 & 3 & 1 & 11 & 12.64 \\ 2012 & & & & & & & & & 1 & & & 1 & 1.15 \\ \text { Total } & 6 & 8 & 1 & 7 & 3 & 9 & 16 & 1 & 5 & 18 & 13 & 87 & 100 \%\end{array}$

Notes: 1. Foreign Language World; 2. Foreign Language and Literature; 3. Foreign Languages Research; 4. Foreign Language Learning Theory and Practice; 5. Modern Foreign Languages; 6. Foreign Language Research; 7. Shandong Foreign Language Teaching Journal; 8. Journal of Foreign Language; 9. Journal of PLA University of Foreign Languages; 10. Foreign Language Education; 11. Foreign Languages and Their Teaching

From Table 2, it can be clearly seen that the literature on BELF has been on rise ever since 1981. However, just a small number of journal articles in this field were published each year. Since 2006 there has been a steady increase in the number of articles published in this field. In 2011, it reached to a peak when 11 published papers appeared in these prestigious journals. Further, Table 2 shows that at least 6 papers were published each year from 2006 to 2011. Based on the data collected, it can be concluded that the quantity of journal papers in BELF have been improved over the past several decades. Nevertheless, among these 87 papers identified, only 4 papers were empirical studies, and accounted for $4.60 \%$ (see Table 3 ). This fact reflects a limitation in BELF studies.

Table 3. The Proportion of Empirical and Non-empirical Studies

\begin{tabular}{lll}
\hline Research methods & Empirical studies & Non-empirical studies \\
\hline Total & 4 & 83 \\
Percentage (\%) & 4.60 & 95.40 \\
\hline
\end{tabular}

Table 4. The Distribution of the 87 Papers by Research Area

\begin{tabular}{lll}
\hline Research areas & Total & Percentage (\%) \\
\hline Teaching methodology, mode and learning strategies & 25 & 28.74 \\
Syllabus design ,course assessment and reform & 8 & 9.20 \\
Testing & 3 & 3.45 \\
Translation studies & 17 & 19.54 \\
Teacher studies & 2 & 2.30 \\
Teaching material studies & 2 & 2.30 \\
Genre analysis & 7 & 8.05 \\
Pragmatics study & 3 & 3.45 \\
Systemic functional based & 8 & 9.20 \\
Needs analysis & 2 & 2.30 \\
Discourse studies & 13 & 14.94 \\
Other & 6 & 6.90 \\
\hline
\end{tabular}

The research areas of the 87 papers can be grouped into 12 categories (see Table 4). Some papers focused on two or more research areas are included in others. From the data displayed in Table 4, several conclusions are apparent. First, BELF literature has focused on various BELF content areas. Second, literature on teaching methodology and mode, learning strategies has made up the largest proportion $28.74 \%$ of work with translation studies $19.54 \%$, the second largest. Taken together this data indicate a close relationship between BELF teaching and research. Translation studies on BELF have been given a lot of attention in English as a foreign language (EFL) context. Third, the fact that literature on syllabus design, course assessment and reform, genre analysis, and systemic functional based studies has accounted for relatively higher proportions of articles, $9.20 \%, 8.05 \%$ and $9.20 \%$ respectively, implies that BELF course design has attracted much more attention. This finding also indicates that the time for relating theory to teaching practice has become shorter. 
Literature in areas such as teacher studies, teaching material studies and testing has made up a small proportion of articles. Therefore, more research work is urgently needed in these fields.

\section{Conclusion}

To sum up, BELF teaching and research in China has had a rapid and steady growth. BELF teaching and research is deeply rooted in the growth of the domestic economy and influenced by the process of globalization. Consequently, each achievement in BELF teaching and research will have a positive impact on economic development and global communications. There is no other subject that can surpass the great effect BELF has produced on international communications.

This research is focused on journal papers published in 12 major academic journals in the field of foreign languages in China. The papers collected may to some extent indicate the trend of the development of BELF teaching and researching and provide readers with reliable references. However, more research is needed to ensure a promising future for BELF teaching and research.

\section{References}

Bai, J. Y. (2011). Research into the Construction of Teaching Contents and Curriculum Consistent with the Industry Standard. Shangdong Foreign Language Teaching Journal, 3, 5-9.

Bao, W., \& Ji, S. J. (2007). A Survey of Competence System for Business English Talents in Higher Vocational Colleges. Shangdong Foreign Language Teaching Journal, 2, 110-114.

Bao, W. (2011). On Teacher Professional Development for Business English Discipline. Foreign Language Research, 2, 122-123.

Cai, L. (2006). Oral business English teaching under the guidance of constructivism. Foreign Language World, 2, $32-36$.

Cai, Y. (2001). An Effective Way of Cultivating Multi-talents- a review over business English courses. Foreign Languages and Their Teaching, 4, 36-38.

Chen, D. C. (2003). Genre Analysis of Business English Letters and its Writing Strategies. Foreign Language Teaching, 2, 52-56.

Chen, D. C. (2007). Ritualized Language in English-Chinese Business Letters and its Translation Principles. Foreign Language Teaching Abroad, 4, 43-47.

Chen, D. C. (2007). Ritualized language in English-Chinese Foreign Trade Letters and its Translation Principles. Foreign Language Research, 4, 43-47.

Chen, J. P., \& Nie, L. L. (2009). On Disciplinary Framework of Business English: Based on Current Researches. Foreign Language Education, 5, 73-76.

Chen, P. (1999). Innovations in the Foreign Trade English Writing Instruction: Genre Analysis and its Applications. Foreign Language Education, 3, 28-30.

Chen, X. J., Wu, J., \& Tang, X. Q. (2010). A Report on the First Forum of Languages and International Business Across Disciplines. Modern Foreign Languages, 2, 70.

Chen, X. L. (2010). Theoretical Issues in Business English Tests. Foreign Language Research, 6, 93-96.

Chen, X. L., Xu, S. H., \& Wang, L. L. (2011). The Construction Model of Business Language-Double Dimension of Ad-Discourse Construction. Foreign Language Education, 3, 23-27.

Chen, Y. (1998). Communicative Approaches in Business English Teaching. Foreign Languages and Their Teaching, 8, 41-42.

Chen, Z. C. (2002). Inconsistent or conflicting English translations of identical orsynonymic Chinese vocabular items:A prominent defect of New Age C-E Dictionary (2000) exposed in 101 specific instances. Journal of Sichuan International Studies University, 3, 130-134.

Chen, Z. M. (2001). Dui Wai Jing Ji Mao Yi Da Xue Xiao Zhi/Annuals of the University of International Business and Economics. Beijing: Press of University of International Business and Economics.

Chen, Z. S. (2002). A Review on the New Age Chinese-English Dictionary. Journal of PLA University of Foreign Languages, 4, 80-83.

Dou, D. Y., \& Cao, Y. (2006). A Multi-level Perspective in Curricula and Teaching of Business English. Foreign Language Education, 6, 53-55. 
Dun, G. G. (2002). Characteristics and Translation of Words in English for Business and Economics. Shangdong Foreign Language Teaching Journal, 3, 37-40.

Fu, M. R. (1999). The Modern Business Styles of the Structure and Language of Business English Practical Writing-LCCI Remarks on Business English Practical Writing Code. Foreign Language Education, 4, 45-47.

Fu, M. R. (2000). Business English Writing Standard and Business English Letter Writing Skills. Foreign Language Teaching Abroad, 1, 33-37.

Gan, C. Y. (2006). Post-Modernist Cultural Context and International Business Negotiation. Journal of Sichuan International Studies University, 5, 73-76.

Gan, C. Y. (2007). The Cultural Logic and Thinking Tracks of Post-Modernist International Business Negotiation. Journal of Sichuan International Studies University, 4, 107-110.

Gu, Z. Z. (2006). Applying Task-based Approach to Business English Teaching. Shangdong Foreign Language Teaching Journal, 3, 79-82.

Guan, C. L. (2005). A Discussion of A needs Analysis Necessary for an Effective Business-oriented English. Foreign Languages and Their Teaching, 3, 40-43.

Hou, Y. F. (1993). Exemplifications of Specialist English in Letter of Credit. Modern Foreign Language, 2, $50-56$.

Hu, G. S. (1990). The Basic Linguistic Characteristics and Techniques in Foreign Set-Tech Trade Negotiations. Modern Foreign Languages, 4, 4-11.

Hu, G. S. (1993). Euphemisms in International Communications. Foreign Language Education, 1, 25-32.

Huang, Y. (1997). The Characteristics and Requirements of the Teaching of International Trade major. Journal of PLA University of Foreign Languages, 5, 76-77.

Inman, M., \& Fu, H. C. (1981). Foreign Languages and America's International Companies. Foreign Language Teaching Abroad, 2, 16-24.

Jiang, Y. J., \& Guo J. C. (1997). Business English and its researching and teaching. Foreign Language Education, 1, 43-50.

Kong, Q. Y. (1997). Practical Professional English-A Course-book Fostering Practical Abilities. Foreign Language World, 4, 28-30.

Li, G., \& Li, B. (2011). On the Translation of Business Contract from the Perspective of Systemic Functional Linguistics. Foreign Language and Literature, 1, 112-115.

Li, H. Y. (2004). Focus on Lexical Chunk Productive Practice in Vocabulary Drilling-A Discussion on Vocabulary Exercise Design of the Course-book "English for Economic and Trade Purposes: an Integrated Course-book". Foreign Language Teaching Abroad, 1, 59-64.

Li, J. R. (2007). Genre Analysis of Business English Emails. Foreign Languages and Their Teaching, 7, 24-28.

Li, M. Q. (2009). A Research of Business English Translation Based on the Principle of "Innovation". Foreign Language Research, 1, 124-126.

Li, M. Q. (2009). A Research of Business English Translation Based on the Principle of "Innovation". Journal of Sichuan International Studies University, S1, 121-124.

Li, R. F. (2004). The Application of Genre-based Approach in Business English Teaching Practice. Journal of Xi'an International Studies University, 1, 68-70.

Li, T. C. (1998). A Discussion on Vocabulary Features of Business English Writing. Foreign Language Education, 2, 53-56.

Li, T. Z. (2006). Advantages of lexical chunks in English writing for foreign trade and their productivity training methods. Foreign Language World, 1, 36-41.

Li, X. P. (2011). Thoughts on the Construction of Communicative Situation in the Teaching of L2 Writing Based on the Practice of Business English Writing. Foreign Language and Literature, 3, 137-140, 148.

Li, X. S. (1997). A Study on the Strategies and Skills of Business Negotiation Languages. Shangdong Foreign Language Teaching Journal, 1, 24-28. 
Li, X. S. (1997). Genre Analysis and Business Discourses. Journal of Foreign Language, 2, 26-29.

Li, Y. X. (2008). How to Translate English Company Names. Shangdong Foreign Language Teaching Journal, $3,109-112$.

Liao, G. R. (2007). Expressive Conciseness on the Basis of Frames and Contexts-A case study on foreign trade English. Foreign Languages and Their Teaching, 11, 12-15.

Lin, T. H. (2004). Three Reflections on the Teaching of International Business English. International Business Studies, 1, 57-61.

Liu, F. G. (1995). Translation in China's Economy and Trade. Foreign Languages and Their Teaching, 3, 44-47.

Liu, F. G. (1999). Studies on Business Chinese-English Translation-Based on language features of Business English. Journal of PLA University of Foreign Languages, 2, 76-79.

Liu, Q. J., \& Li, J. (2006). Research on the Curriculum and Mode of Business English Teaching. Shangdong Foreign Language Teaching Journal, 6, 77-79 .

Liu, Q. J. (2002). Innovation Teaching and Ability Cultivation in Business English. Shangdong Foreign Language Teaching Journal, 2, 46-48.

Liu, Q. J. (2008). The Practice and Research of Interpretation Course in Business English Teaching. Shangdong Foreign Language Teaching Journal, 3, 78-80.

Liu, Q. J. (2010). Analysis on the Characteristics of Business English Vocabulary and Comments on Business English Translation. Foreign Language Teaching Journal, 3, 89-93.

Liu, S. L. (2005). Trends in the Teaching of International Business Negotiation English. Foreign Language Education, 5, 32-36.

Mark Ellis, \& Christine Johnson. (1994). Teaching Business English. New York: Oxford University Press.

Mo, Z. S., \& Sun, W. J. (2010). A Survey on the Current Situation of Business English Writing Course books. Foreign Language Education, 5, 81-85.

Mo, Z. S. (2008). Research on business English education based on economics of language. Foreign Language World, 2, 67-74.

Pan, D. T. (2010). On the Translation of Business Text from the Perspective of Skopos Theory. Foreign Language Research, 5, 120-122.

Peng, A. H. (2009). Exploring the Practical Principles of Translating: Business Publicity Texts of Traditional Chinese Medicine from an Intercultural Perspective. Journal of Sichuan International Studies University, S2, 107-109.

Qin, L. L. (2004). Studies on the Translation of Business English-From a multi-perspective. Foreign Languages Research, 4, 62-65.

Qiu, T. H. (2000). Positive Pragmatic Strategy Used in International Business and Trade Negotiations. Foreign Languages and Their Teaching, 4, 41-44.

Ruan, J. Z. (2005). On the Course Design of Business English Writing and Teaching Model. Foreign Language Teaching Journal, 1, 57-59.

Ruan, J. Z. (2005). On the course objectives of college Business English and its teaching principles. Foreign Language World, 3, 28-33.

Rui, Y. P. (2011). Subjective Function in the Discourse Construction of Business English. Foreign Language Research, 5, 136-138.

Sang, S. M. (1996). Language Features of Foreign Trade English Contract and its Translation. Foreign Languages and Their Teaching, 6, 14-17.

Shi, C. R., \& Bai, Y. (2012). A Review of the Research on Business English Translation in the Past Decade. Journal of PLA University of Foreign Languages, 1, 82-87.

Sun, X. C. (1993). The Meaning of Compound Words Composed of here(there) + prep. In Business English. Shangdong Foreign Language Teaching Journal, 4, 39-40.

Tan, H. J. (1999). Business English Teaching and Functional Approaches. Journal of PLA University of Foreign Languages, S1, 62-64. 
Tang, J. (1998). Research on Typical Polite Business English Language Mechanisms. Foreign Language Education, 4, 18-21.

Wang, F. (2009). Instructional Design and Evaluation of Business English(BE) Based on Networked Connectivism. Foreign Languages and Their Teaching, 11, 38-41.

Wang, H. L., \& Guo, J. R. (2006). Genre Analysis and Promotional Texts in Business Settings. Foreign Language Education, 4, 36-41.

Wang, H. L., \& Guo, J. R. (2005). Genre Analysis of English Print Advertisements. Foreign Language Education, 1, 29-32.

Wang, L. (2004). The Register and Language Features of Foreign Trade Negotiation English. Foreign Languages and Their Teaching, 4, 13-15.

Wang, L. F., \& Jiang, J. L. (2011). English Test for International Business of China: Its Design, Reliability \& Validity Analysis. Foreign Languages and Their Teaching, 6, 38-43.

Wang, L. N., \& Duan, J. (2010). The Case Study Method in Business English Teaching. Foreign Language and Literature, 4, 100-104.

Wang, Z. Y. (1995). Problems with Foreign Trade English Teaching. Foreign Language Research, 2, 69-71, 45.

Wei, B. L. (1994). British Cambridge Business English Test. Foreign Language Teaching Abroad, 1, 8, 39.

Wen, J. (1995). In Terms of English for Economic and Trade Purposes Teaching: The Necessity of Composing a dictionary of English for Economic and Trade Purposes Teaching. Foreign Language Teaching Abroad, 1, 14-16.

Wen, X. M. (2010). An Empirical Study on Vocabulary Learning Strategies among Business English Majors. Foreign Language and Literature, 5, 138-140, 149.

Wu, J. X. (1990). Fuzzy Language in Foreign Trade Negotiation. Modern Foreign Languages, 4, 17-20.

Xiao, H. (2008). On the Reform of the English Curriculum for Non-English Major Postgraduates in Financial Institute: a Case Study. Foreign Languages and Their Teaching, 8, 37-39.

Xiao, Q. (2008). The Appraisal and Its Functions in Business English Conversation. Foreign Languages and Their Teaching, 6, 15-17.

Xiao, Y. P. (2011). A Pragmatic Analysis of the Requesting Strategies in International Business Emails. Foreign Language Education, 6, 35-39.

Xu, J. (2004). Genre Analysis on Business English Letters. Journal of Xi'an International Studies University, 1, 26-29.

Xu, J. (2010). Business English Studies: A Functional Linguistics Perspective. Foreign Language Research, 5, 56-60.

Xu, J. (2011). Translation Studies on Business English from the Perspective of Evaluation Theory. Journal of PLA University of Foreign Languages, 6, 90-93, 111.

Yan, M. (2010). The Theoretical Construction of Discourse Community. Foreign Language Research, 6, 89-92.

Yu, G. (2007). Social Reflection by the Evolution of Business English Words and Expressions. Shangdong Foreign Language Teaching Journal, 2, 69-73.

Zeng, L. S. (2011). A Contextual Parameters-based Study of the Cognitive Mechanism for Interpreting Conceptual Meaning Transmutation - Theories and Methods in Teaching Translation of English News about Current International. Foreign Language Education, 6, 8-12.

Zhao, S. R. (2009). Discussion on Application of Situational Language Teaching in Business English from the Perspective of Need Analysis. Foreign Language Teaching Journal, 2, 68-71.

Zhou, M. Z. (2006). The Contextual Factors and Meaning-Determination in the Business Text Translation. Foreign Languages and Their Teaching, 11, 59-61.

Zhou, R. Q. (2001). A Pragmatic Analysis of the Apologizing Strategies in Business Settings. Foreign Language Education, 4, 92-95.

Zhou, W. X. (2011). Genre Analysis of Business English Based on Discourse Community. Foreign Language Research, 6, 48-50. 
Zhu, Y, Li, \& J. Y. (2004). A Contrastive Study on the Chinese and English Speech Act of Refusal in Shopping Activities. Foreign Language Education, 1, 19-22.

\section{Copyrights}

Copyright for this article is retained by the author(s), with first publication rights granted to the journal.

This is an open-access article distributed under the terms and conditions of the Creative Commons Attribution license (http://creativecommons.org/licenses/by/3.0/). 